\title{
The impact of the Polar Code on risk mitigation in Arctic waters pÿ: a toolbox for underwriters?
}

\section{Gritsenko, Daria}

2018

Gritsenko , D , Fedi , L \& Faury , O 2018 , ' The impact of the Polar Code on risk mitigation pÿin Arctic waters : a toolbox for underwriters? ' , Maritime Policy and Management, vol. 45 , no. 4 , pp. 478-494 . https://doi.org/10.1080/03088839.2018.1443227

http://hdl.handle.net/10138/308915

https://doi.org/10.1080/03088839.2018.1443227

acceptedVersion

Downloaded from Helda, University of Helsinki institutional repository.

This is an electronic reprint of the original article.

This reprint may differ from the original in pagination and typographic detail.

Please cite the original version. 


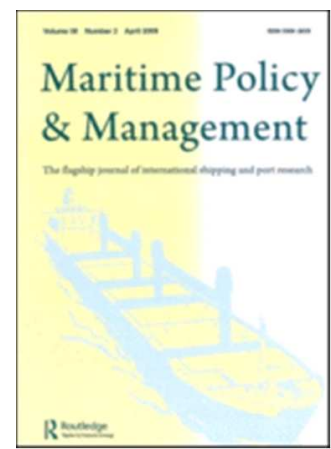

The impact of the Polar Code on risk mitigation in Arctic waters: a 'Toolbox' for underwriters?

\begin{tabular}{|r|l|}
\hline Journal: & Maritime Policy \& Management \\
\hline Manuscript ID & TMPM-2017-0073.R1 \\
\hline Manuscript Type: & Special Issue Article \\
\hline Keywords: & Polar Code, Arctic, Risk, Underwriters, Hazard sources \\
\hline \multicolumn{2}{|l}{} \\
\hline
\end{tabular}

SCHOLARONE ${ }^{\text {"x }}$

Manuscripts 


\section{The impact of the Polar Code on risk mitigation in Arctic Waters: a 'Toolbox' for} underwriters?

\section{Introduction}

During the past decade, interest in Arctic shipping has increased. The rapid melting of sea ice suggests that the Arctic Ocean may become ice-free (IPCC 2014), thus more suitable for commercial navigation. Yet, Arctic navigation will remain risky due to the existence of multiple hazards, such as drifting ice, restricted visibility, extreme temperatures leading to icing, inaccurate charts and remoteness (Blanco-Bazan 2009; Haavik 2017).

On January $1^{\text {st }} 2017$, the 'International Code for Ships Operating in Polar Waters', referred to as the Polar Code (PC), entered into force through a direct integration into the International Convention for the Safety of Life at Sea (SOLAS 1974/1988) and the International Convention for the Prevention of Marine Pollution from Ships (MARPOL 1973/1978). This instrument was negotiated under the auspices of the International Maritime Organization (IMO) aiming to define enhanced safety and environmental standards for future Polar shipping. The PC follows a 'risk based approach' (IMO 2014), meaning, it explicitly identifies the main risks existing in Polar areas, their potential consequences and enacts imperative and non-mandatory measures to mitigate such identified risks.

Risk assessment and mitigation in shipping in general (Goerlandt and Montewka 2015; Lam and Lassa 2017; Luo et al. 2017; Uğurlu et al. 2017) and in Arctic navigation specifically, has been dealt with in various strands of literature. A comprehensive review of previous research on Arctic shipping can be notably found in Kum and Sahin (2015). The technical approach emphasized the specific polar risks, their acuity, the severe consequences of their occurrence (Loughnane et al. 1995; Kum and Sahin 2015) requiring new predicting models (Bergstrom et al. 2016; Fu et al. 2016). Numerous studies have highlighted the importance of sound maritime insurance for operations in Arctic waters and actual difficulties due to the lack of statistics (Verny and Grigentin 2009; AMSA 2009; Lasserre 2014; Kiiski 2017). Sarrabezoles et al. (2014) argued that the risk assessment process has been influenced by the IMO and classification societies while underwriters have faced the absence of standard procedures to evaluate Arctic risks. On the other hand, a legal approach has provided a thorough analysis of the PC substance and regulatory design (Jensen 2008; Molenaar 2008; Stokke 2011; Henriksen 2014; Bai 2015; Fedi and Faury 2016). Despite the scholarly interest in risk 
assessment and management in Arctic shipping, the relationship between the PC provisions and risk appraisal by marine insurers remains poorly understood and explored.

The objective of this research is to address this gap. First, it analyzes the new legal framework laid down by the PC as a set of requirements that underwriters have to take into consideration prior to insuring an Arctic journey. Second, it evaluates the PC managerial outcomes for underwriters to provide an adequate understanding of this new regulation in the functioning of Arctic shipping insurance. We draw on the socio-legal strand in shipping research (Sampson and Bloor 2007) to uncover the relationship between insurers' expectations, practices and the implementation of international shipping regulation.

In this study, the authors conduct empirical research to clarify whether the PC is a 'toolbox' for underwriters insuring vessels in the Arctic. We use a metaphor of 'toolbox' to illustrate the role of the PC in Arctic shipping insurance. It means that the PC legal framework provides a set of operational risk management tools and when insurers need a tool to do their work associated with risk evaluation, they can pull it out of this box and use it for a task at hand.

The remaining part of the paper proceeds as follows. Section 2 provides a literature review on Arctic shipping risk features and ship insurability concerns. It also highlights a research gap as regards the PC contribution to the risk appraisal that represents a crucial part of the insurer's role. Section 3 presents the methodology of the study. Section 4 introduces the results of the investigation based on the interviews of experts. The main findings on Arctic ship insurability and insurance company operations in light of the PC as a 'toolbox' and the 'Polar Code Paradox' are discussed in Section 5. Finally, Section 6 outlines conclusions and future research agenda.

\section{Literature review}

Maritime transportation is an industry involving different types of risks (Wang 2006; Guedez and Teixera 2011). Risk is usually considered as a function of probability of loss and undesired consequences (Vilko and Hallikas 2012). During the last decade, scholars and stakeholders themselves have paid more attention to maritime transport risk analysis, risk management and risk hierarchy (Guedez and Teixera 2011; WEF 2013; Goerlandt and Montewka 2015; Lam and Lassa 2017). Notwithstanding significant maritime safety improvements on the ten-year loss average (ALLIANZ 2017) and greater accuracy in identification of marine accident sources (Uğurlu et al. 2017), a recent study revealed that $63 \%$ of the world's shipping accidents are recurrent and many ships suffer more than one accident during their operations (Luo et al. 
2017). In addition, the shipping industry and seaports are facing greater risks caused by the rapid environmental change (Notteboom and Lam 2014). Beyond the conventionally known operational and environmental risks addressed in the mandatory IMO conventions (WEF 2013), the maritime sector indubitably faces increased risks associated with weather conditions involving costly disruptive scenarios (Andrey 2010; IPCC 2011; Lam and Su 2015; Lam and Lassa 2017). Climate extremes also pose significant challenges in terms of risk assessment due to their unpredictability (Lam and Lassa 2017).

The impact of global climate change is particularly visible in the Arctic where it causes progressive retreat of the sea ice surrounding the North Pole (Corbett et al. 2010). Consequently, maritime traffic in the Arctic region is expected to grow in the coming decades (Kum and Sahin 2015). In response to this expectation, the IMO adopted the Polar Code (PC) aiming to reduce the risks of operating in polar waters. There is an abundant literature covering various aspects of Arctic shipping: Arctic shipping routes and profitability, environmental impacts, Arctic politics - legal and strategic factors - and navigation (for an overview see Kum and Sahin 2015). However, there exists a research gap regarding the direct links between the PC provisions and ship insurability. The present study places emphasis on the impacts of PC provisions on the marine underwriters' risk assessment for Arctic navigation. In what follows, we elaborate on the Arctic shipping risk features, the question of insurability in Arctic waters and the PC contributions to the risk appraisal.

\subsection{The Arctic shipping risk features}

Research has clearly demonstrated that physical and operational conditions in the Arctic increase the level of conventional shipping risks (Haavik 2017). According to recent studies, remoteness is a major concern for shipping firms (Lasserre et al. 2016), as well as the extreme natural environment in itself (Haavik 2017). Moreover, the harsh environment profoundly influences human and technical systems of a vessel (Montewka et al. 2015).

As regards risk occurrence, a number of studies have demonstrated its acuity in Arctic waters. Loughnane et al. (1995) reported a 19 times higher incident rate in the Arctic compared to open-water. As for the main accident causes, the lack of crew experience was identified as the primary source (Tikka et al. 2008). According to the Arctic Marine Shipping Assessment Report (AMSA 2009), human factor/accident to person represented the main contributor to the total number of accidents $(76.7 \%)$ due to inattention, heavy weather, age and lack of communication. The second highest contributor was collisions and groundings. A detailed survey based on 19 years' analysis of Arctic marine accidents from 1993 to 2011 (Kum and 
Sahin 2015) confirmed that accident to person was the most occurring accident and stressed the significance of crew training and competence requirements. This study pointed out fishing vessels and passenger or cruise ships represented a significant part of the number of injuries and incidents.

While in 2006 there were only eight incidents reported in the Arctic, the number increased to 55 in 2014, 71 in 2015, and 55 in 2016, including one total loss (Allianz 2017). This significant increase within only one decade justified why Arctic shipping risks require accurate evaluation and mitigation measures notwithstanding the limited historical data available (Fu et al. 2016). To address this challenge Bergstrom, Erikstad, and Ehlers (2016) proposed a framework for holistic goal- and risk-based design of Arctic Maritime Transportation Systems (AMTS) with the aim of apprehending the whole navigation in Arctic waters instead of focusing on each vessel. Other researchers designed a probabilistic model for predicting ship besetting in ice (Fu et al. 2016). Scholars have demonstrated that Arctic navigation is 'relatively novel compared to traditional navigation' (Fu et al. 2016) and operators are confronted with 'non-traditional risks' due to climate extremes (Liam and Lassa 2017). This specific Arctic context with inherent potential navigational hazards has led to specific ship insurability.

\subsection{Ship insurability in the Arctic}

Marine insurance responds to a fundamental need to cover a ship against the economic consequence of its loss or damage (Tetley 2003). The amount of the insurance premium generally depends on the underwriter's estimation of the degree of risk that the vessel will incur a loss and on the amount of indemnity they will have to pay out (Bonassies and Scapel 2016). To sum up, the insurer subscribes to a risk of loss which has a price: the greater the risk, the higher the premium. Consequently, the underwriter shall take into consideration different components applicable to the risk as shown in Table 1 that may affect the likelihood of loss occurrence and the amount of the insured party's liability (Bonassies and Scapel 2016). As a result, assessing risk in the Arctic implies a different approach comparing to the risk assessment outside Arctic waters.

Insert Table 1 Key factors of insurance premium outside Arctic

Ship insurability for Arctic navigation significantly differs from open waters as regards practices and insurance premium (Verny and Grigentin 2009; AMSA 2009; LLOYD'S 2011). Arctic trade is indeed not usual for underwriters representing only a small part of the global 
marine insurance market (CEFOR 2016; IUMI 2017). One still observes both a lack and a limit of historical loss records compared to other shipping trades and reduced to two decades approximatively (Kum and Sahin 2015; ALLIANZ 2017). This lack of 'comprehensive statistics' required to assess risks in Arctic waters significantly impacts insurance coverage (Kiiski 2017; Gold 1999). As a matter of fact providing such cover remains a 'complex' or 'difficult' task (Johannsdottir and Cook 2014; MARSH 2014). Though Hull and Machinery (H\&M) insurance is underwritten on a yearly basis, it turns into a one-off voyage policy for Arctic navigation insofar as most routes are only passable for limited summer periods (Ørts Hansen et al. 2016). This explains why most Arctic waters are excluded from H\&M policies and usually implies additional premiums (Bonassies and Scapel 2016). According to Lajeunesse (2012), Arctic insurance premiums are around 150-300\% higher than in ice-free waters while others argue reasonable rates (Sarrabezoles et al. 2014) or comparable levels to the Suez Canal (Erikstad and Ehlers 2012). A recent synthesis of additional Arctic premiums has shown a variation between 0-200 per cent (Kiiski 2017).

Moreover, the nature and the number of risks associated with Arctic navigation have to be identified and measured (LLOYD'S 2011; MARSH 2014). The four key factors outlined in Table 1 are complemented by specific parameters (Figure 1). Underwriters emphasize technical, legal, logistical, human and contractual considerations (CEFOR 2012). As regards technical aspects, the vessel's suitability is evaluated, including ice class, list of navigational equipment including radar capable of detecting floating ice, echo sounder, iridium satellite phones, lifeboats, spare parts and chart systems. As for legal aspects, the ship has to comply with SOLAS provisions and the Safety Management System (SMS) for trading in the Arctic (ISM Code 3-2-2) in particular. For logistical preparedness, the insured is expected to be aware of weather conditions, ice and weather charts and forecasts. The duration, itinerary, suitable ports of call, forbidden areas, nearest Search and Rescue (SAR) equipment or repair facilities and recourse to ice-pilot or icebreaker are clearly determined. Concerning the human aspect, the crew competence shall be accurately assessed on such criteria as: good working knowledge of English language, and Russian for the Northern Sea Route (NSR), Arctic experience, watchkeeping plans, pilot on board. As regards the contractual aspects, the main role and duties of each co-contracting parties involved in the voyage are identified notably for salvage issues. Insert Figure 1. Fixing insurance premium in the Arctic context

Faury (2015) reported that underwriters have recently adopted a collaborative approach for risk assessment by informally gathering general and technical information from other 
insurers, brokers, classification societies and former masters in order to deepen the risk appraisal for each potential insured. As a result Arctic shipping insurability involves a case-bycase approach in accordance with an empirical method that differs from traditional shipping since insurance market price for a certain type / size of vessel, trade or voyage is applied (Kiiski 2017). For the Arctic, even if knowledge on insurance practices has recently emerged, it seems that this market price does not actually exist. This raises the question of PC contributions to Arctic risk appraisal and therefore to ship insurability.

\subsection{The Polar Code contributions to Arctic risk appraisal}

Existing literature has not yet suggested that PC provisions could facilitate risk appraisal and represent a significant component of upcoming Arctic marine insurance. Nevertheless, the PC safety and environmental protection measures are expressly designed to mitigate the likelihood of accidents (Polar Code Preamble note 35) and enable us to consider that these new IMO requirements shall impact ship insurability.

The PC is characterized by two dimensions: it is risk- and goal-based (Henriksen 2014). Firstly, it identifies and explicitly lists the key hazards inherent to polar shipping affecting the probability of risk occurrence and/or more severe consequences (IMO 2014). The list of hazard sources includes sea ice, topside icing, low temperatures, extended periods of darkness, high latitude, 'vagaries' of weather conditions, remoteness, lack of data (charts), lack of crew experience, lack of SAR equipment and the sensitivity of the environment. Secondly, the PC follows a holistic approach (Fedi and Faury 2015) in addressing risks in polar navigation which were not 'adequately mitigated' by previous IMO provisions (Henriksen 2014). To this end the PC enacts mandatory rules (Part I-A on Safety measures and Part II-A on Pollution Prevention) and recommendations (Part I-B and Part II-B).

Regarding mandatory safety rules, ships operating in polar areas have to meet specific requirements defining vessel's capabilities and operational limitations certified by two fundamental new documental prerequisites. The first one is the Polar Ship Certificate ('PSC' hereafter) showing evidence that the ship has been satisfactorily surveyed (structure, equipment, fittings, radio station arrangements and materials) and has received her ice class (A, $\mathrm{B}, \mathrm{C})$ according to her ability to sail through or in ice-covered areas. This certification requires an assessment to establish procedures in accordance with operational limitations taking into account anticipated scenarios of operating, environmental conditions and hazards the vessel may face inter alia low ambient air temperature, ice, high latitude, abandon of the ship, remoteness and the effect of polar conditions on crew performance. The methodologies used 
for assessing operational capabilities and limitations in ice shall be based on the 'Polar Operational Limit Assessment Risk Indexing System' (POLARIS) developed by both the International Association of Class Societies (IACS) and major Arctic nations such as Canada, Denmark, Finland, Russia and Sweden (IMO 2016; Kujala et al. 2016).

The second documental requirement is the Polar Water Operational Manual (PWOM) that defines specific procedures for mitigating risks by ensuring that the vessel operates within or beyond formal limitations or capabilities. Voyage planning is a fortiori required 'to ensure that the Company, master and crew are provided with sufficient information to enable operations to be conducted with due consideration to safety of ship and persons on board and, as appropriate, environmental protection' (Chap. 11 PC). For instance, when a route is chosen, a maximum amount of information on hazards, hydrography, navigation aids, extent and type of sea ice, vicinity of icebergs, places of refuge or remoteness from SAR capabilities is collected.

The PC therefore implements mandatory preventive measures through proceduralization of risk mitigation, and creates international mandatory standards for Arctic operators. The authors argue that the PC provides an appropriate framework for risk assessment in Arctic waters. The documental prerequisites, the voyage planning, the appropriate qualification and training of officers indeed contribute to reinforcing the vessel's suitability for Arctic navigation and strengthening its 'polarseaworthiness' (Cullen 2015). In the medium run, the PC provisions shall be incorporated into insurance marine contracts and chartering or sea carriage contracts. Then insurers shall be legally entitled to verify the compliance with standards and documents prior to providing H\&M insurance. This close relationship between the PC requirements and the insurability of vessels can be analyzed by uncovering underwriters' point of view.

\section{Methodology}

The data for this research comes from interviews, professional reports and academic articles. We collected available professional reports produced by maritime insurance companies over the period 2011-2016. Since the majority of commercial shipping is expected to take place in the Northern hemisphere, we limit our investigation to Arctic shipping (Gritsenko and Kiiski 2016). Insofar as there is a wide range of hazards that impact the integrity of the ship, the crew and the environment, we decided to look at two markets, namely H\&M insurance offered by underwriters and marine liability cover provided by Protection and Indemnity Clubs (P\&I). 
The interviews with professionals currently employed in marine insurance companies took place between January $1^{\text {st }} 2017$ and March $15^{\text {th }} 2017$ (Annex I). We utilized thematic analysis, a method that involves the search for and identification of common threads that extend across a set of interviews (De Santis and Ugarriza 2000). Interviewing experts is a popular method of data collection when investigation pertains to future development, as other empirical data is not available covering the future. According to Gläser and Laudel (2009) experts are people who possess special knowledge of a phenomenon under investigation. Thematic analysis allows identifying, analyzing and reporting themes within data by following four steps: generating initial codes by exploring features of the data systematically appearing across the whole set, collating codes into potential themes, generating a thematic map, refining the themes and the overall story that the analysis tells, potentially selecting compelling extract examples (Braun and Clarke 2006). We applied the same technique to interviews and to professional reports. Finally, we produced a report of the analysis (Section 4), that relates the analysis back to the research question and the academic literature. We also produced visual displays to explicate the results of the analysis (Miles and Huberman 1994).

We used purposive sampling to identify ten leading insurance companies located throughout Europe: Finland (2), France (4), Norway (2), and Russia (2). The selection criterion was a record of providing marine insurance for the Arctic operations. The interviewees were mostly Heads of Marine Insurance Departments and P\&I Managing Directors. Notwithstanding a relatively small number of interviews, the companies selected cover the majority of commercial vessels using the NSR, currently the most trafficked area in the Arctic (Ørts Hensen et al. 2016). As illustrated the Arctic shipping market is small (Sarrebezoles et al. 2014; Lasserre et al. 2016; Pryun 2016) and the Arctic marine insurance can be considered as a niche market (LLOYD'S 2011; MARSH 2014) representing around USD 5 million of gross premium income compared to USD 27.5 billion of the global insurance marine premiums in 2016 (CEFOR 2016; IUMI 2017). Accordingly, few companies have the experience and the capacity to insure such merchant vessels. Thus, the selected companies are economically representative of the Arctic marine insurance market.

The aim of the interviews was to reveal the impact the PC adoption may have on vessels' insurability and on operations of marine insurance globally. The main issue we sought to capture was insurers' expectations related to the $\mathrm{PC}$, their attitudes and practice change. To do so, we developed an interview guide organized in eight topics as shown in Appendix 2. The interviews lasted ca. 45 minutes up to one hour and were conducted both in person and by phone 
following the interview guide, written up and sent for approval to the interviewees upon request. All respondents were granted anonymity. We followed the conversational strategy to interviewing that seeks to reproduce a natural flow of an interaction (Patton 2002), an approach generally used when interviewing experts (Berry 2002). We observed significant agreement between interviewees on the main topics, which allows us to conclude a high degree of saturation (Glaser and Strauss 1967).

\section{Findings}

The findings of the interviews highlight a number of benefits and shortcomings of the PC provisions. The respondents laid out their views on the economics of the PC and their considerations regarding the worst-case scenario. Finally, the questions of the underwriters' practices and if the PC could be considered as a 'game changer' in their risk appraisal were related to $\mathrm{PC}$ implementation.

\subsection{Benefits of the Polar Code}

Taking into consideration that the risk assessment is often subjective and varies from one underwriter to another, the interviewees unanimously consider that one of the main benefits of the PC is to provide a uniform structure to risk management. The mandatory use of the 'PSC' and the PWOM allows underwriters to standardize the parameters to look at in order to mitigate environmental, technical and human risks. As regards the environmental risk, the risk related to ice (ice accretion, thickness and concentration) is considered by all participants as properly stressed in the PC, which provisions focus on the vessel's technical parameters and crew training to avoid such risk occurrence. The requirement for the ship-owner and/or captain to plan the journey in advance is considered by a majority of those underwriters as a good practice to avoid grounding and risks related to ice.

Concerning the technical risk, Finnish, Russian and Norwegian experts agreed on the relevance of the PC to address technical issues. Up to the PC, pursuant to Art. 234 of the United Nations Convention on the Law of the Sea (UNCLOS 1982), each coastal country had the possibility to impose its own requirements making the investment and navigation in the Arctic a complex operation for ship-owners desiring to invest in ice class vessels. According to seven interviewees, the PC classification system (A, B, C) enables the same ice class vessels to sail through the different costal states without additional documentation. Besides, one Norwegian interviewee suggested that the PC will help ship-owners to carry out proper risk assessment 
before they come to the insurance company. A vision shared by a French underwriter: "if there is a vessel with a Polar Class, I can know it's good".

As for the human risk, the PC also provides a framework for ensuring the officers' competency and experience as it imposes a better preparation to operate in the Arctic (notably mandatory equipment, crew training manual, fatigue and emergency training guidelines in PWOM). The importance of experience and training was highlighted by most of the participants.

Finally, the adoption of the PC is also seen as a step towards opening the Arctic market to new stakeholders. Thus, the PC is expected to assist both underwriters and ship-owners that have never worked in the Arctic, and potentially encourage navigation in the polar areas. Hence it solves the topical issue of missing data. "An increase of activity shall supply more data on Arctic navigation that can be further used for improving the risk assessment procedure," affirms a French insurance leader.

\subsection{Shortcomings of the Polar Code}

For P\&I Clubs, the provisions of the PC were seen as less relevant than for the H\&M underwriters. Major salvage operations, in particular related to passenger vessels and an oil spill are the risks most relevant for the P\&I in the Arctic. According to eight interviewees, infrastructure shortage and the lack of connectivity due to limited satellite coverage are not addressed by the PC. The absence of a Heavy Fuel Oil (HFO) ban and insensitivity to light ice conditions were seen as additional deficiencies of the PC. The PC provides a general framework on environmental protection, nonetheless, the tools for environmental management in the sensitive Arctic area are too vague and 'too light' compared to those dealing with technical safety requirements.

Moreover, as stated by one French underwriter, experience is not taken into consideration in the PC. In the same direction a Finnish expert considers an older vessel with an experienced captain preferable to a newer ship with a younger captain. Hence, the underwriters expect that the PC shall make it easier to receive relevant information about the training.

Another major concern is that the PC does not cover fishery boats and yachts which may be more sensitive to ice conditions. A French participant underlines "that ice accretion is not rare and particularly on fishing vessels". While the PC concentrates on heavy ice conditions, it is less constraining with light ice which represents a potential risk for the hull, as has been noted by one Norwegian interviewee. Insofar as the ice melts, the area of open water grows and so 
does the risk of drifting ice as a cause of claims for light ice class vessels. Given the rapid change of the sailing conditions in the Arctic, including drifting ice, the definition of ice class vessels by ice thickness as described in the PC does not facilitate proper risk management.

Finally, the PC does not provide insurance companies with reliable tools to monitor compliance. For instance, the 'PSC' serves as a guarantee of technical fulfilment, yet, since it is issued at a defined time, nothing guarantees underwriters that the vessel still meets the PC basic requirements at the moment of insurance subscription. The same applies to the crew composition and its qualifications. In most cases, the underwriters do not validate the truthfulness of certificates by a visit on board. Even though two participant, one Russian and the other French, insist on the current lack of qualified surveyors, the flag state registration and the IACS classification society remain two significant criteria in the risk appraisal. Thus, a relationship of trust must be created and maintained between underwriters and ship-owner.

Insert Table 2 Polar Code and risk mitigation: underwriters' view

\subsection{The economics of the Polar Code}

The procedure for risk assessment conventionally used in the marine insurance industry applies to the Arctic, which was confirmed by the interviews. The interviewees explained that they rely on the international legal framework and information acquired from various stakeholders to define the premium as highlighted in Figure 2. The certification process included in the PC is seen by the experts as an advantage in assessing technical and human risks, but not a disruptive practice to the extent that IMO certificates represent only a part of the underwriter's evaluation. Due to the lack of direct relations with the crew, underwriters rely on ship-owners, brokers or leading insurance companies as the main source of information. To ensure documental compliance some insurers use an independent inspector to survey the concordance between the certificate and the vessel, especially for old ice-class ships.

The interviewees emphasized that the PC does not provide them with the advanced information they would like, namely, historical data. In order to compute the premium a Finnish participant confirms they need to know the probability, the frequency and the average claim, parameters they have not had until now. A French underwriter affirms that "the insurance premium is mainly defined according to the market" and "the PC is too young to have an impact on the premium since it only applies to new ships as of 1 January 2017". Thus, they unanimously consider that the PC will have little or no impact on the process of premium calculation. 
The dearth of historical records was unanimously considered as a main factor that complicates the premium computation and the economic cost of claim assessment. Participants are positive that more data will be generated once more traffic goes to the Arctic, and so the information shortage will be resolved. Until such a time, ship-owners have to act on technical and human elements or on the warranties subscribed if they want to reduce the premium rate.

Regarding the additional premium policy, a French P\&I representative explains that the Clubs have no specific rules thus far, a vision shared by a Norwegian interviewee who stresses the non-existence of an additional premium: the P\&I cover is given or not, being a matter of acceptance or refusal.

Insert Figure 2 Fixing insurance premium in the Arctic context

From an economic aspect, all underwriters agreed on the 'astronomic' cost a claim per passenger would represent in the Arctic and most of them took as example the case of the MSC Concordia. They considered that the sinking of a cruise vessel represented the "worst-case scenario" in the Arctic involving huge economic, human and ecological impacts. One French underwriter estimated the cruise vessel value around one billion dollars, considering the operational issues of repair in Arctic and the time cost once the vessel is immobilized. As regards human consequences, the risks linked to a disaster occurring in the harsh environment, notably risk of injury or death, can have considerable impacts worsened by the difficulties of evacuation and repatriation of passengers and crew, a vision shared by several participants. Human loss similar to the Titanic catastrophe cannot be excluded and all participants agreed that the Arctic is not ready to bear such a 'worst-case scenario'.

A possibility of a oil tanker sinking was presented as another source of major negative economic, human, and ecological impacts. Some interviewees stressed the economic cost of a wreck removal made mandatory by the Nairobi Convention. Remoteness is a major cost factor, as it makes any action (salvage, repair or oil clean up) excessively expensive and heightened by the lack of SAR capabilities.

\subsection{Changing practices: the PC as a game changer?}

The interviews demonstrated that while the PC can be seen as a 'giant' step in terms of international cooperation on ensuring safety of navigation in polar waters, it is seen as a 'storm in a glass of water' by underwriters. The PC is a useful 'toolbox' as it codifies the risk assessment procedure and emphasizes risks that may be underestimated by the actors not familiar with the polar navigational conditions, but it does not impact the premium computation 
and does not solve the issue of data shortage. According to the interviewees, the PC provisions do not represent an insurance paradigm shift: the PC does not change the way underwriters operate. That is why the PC is not considered as a 'game changer' - that is, a regulatory instrument that substantially changes the practices in the insurance market.

Crew experience, 'PSC', season of navigation, ice condition forecasts along the planned route, age of the vessel, destination, transit, transit time are the elements of the PC, yet, the same issues were already analyzed by underwriters already before the PC entered into force. The NSR Administration Rules for defining the basic requirements for Arctic navigation are still commonly used as a basis for the insurability of a vessel planning an Arctic voyage. According to the interviewees, the main barrier for risk assessment and premium fixing procedures is the lack of historical data. Obviously, the PC, which is a legal framework and not a database, cannot assist in this regard. There are consequently major areas where insurance practices are not expected to change, at least not in the short run. Companies still operate on a case-by-case basis, where the insured's history, due diligence, the global risk represented by the client, including Arctic and no Arctic shipments are among the key parameters. A French participant representing a leading company pointed out that "if the underwriter only has to insure one Arctic journey, he'll certainly refuse the cover. The client's risk is globally evaluated and this enables or not the specific insurance coverage for the Arctic voyage".

\section{Discussion}

The interviews have confirmed the PC represents a significant mandatory regulatory tool for Arctic navigation. Meanwhile a number of unsolved issues remain at this stage of the PC enforcement resulting in a certain 'Polar Code paradox'.

\subsection{The PC as a 'tool box'}

The PC better structures Arctic navigation through international safety and environmental protection standards reinforcing ship-owners' due diligence for appropriate 'polarseaworthiness' (Cullen 2015). These binding standards harmonize previous disparate national provisions on Arctic shipping (Chircop 2013; Fedi and Faury 2016) and the potential Arctic navigational hazards are clearly provided (Fu et al. 2016). The operational risk assessment required by the 'PSC' and PWOM allows ship-owners to anticipate a wide range of numerous hazards (FORUM PAME 2017). That is why it can be argued that the PC provisions standardize the risk evaluation in polar waters and the absence of such a procedure was a handicap for underwriters (Sarrabezoles et al. 2014). The PC indeed regulates and facilitates a 
part of the underwriters' role when they have to evaluate ship suitability for an Arctic voyage. Accordingly, the PC can be considered as a 'toolbox' related to risk mitigation and assessment for underwriters. In addition, they could play an active role in the faster PC implementation by incorporating its main requirements into their contracts. The PC is also a tool for Arctic newcomers who are potential insured parties.

Nevertheless, the PC effectiveness on risk mitigation in the Arctic will depend on the actual enforcement of its current provisions (AMSA 2017). An institutional support thereby appears unavoidable if the PC is not to remain a soft-law instrument (Johannsdottir and Cook 2014). If IMO parties are the first concerned in harmonizing their national legislations in accordance with the regulatory framework, Port State Control shall be determinant to monitor the actual enforcement through harmonized guidelines (Cariou and Wolff 2015). The fact that seven states out of eight Arctic Council members (Canada, Denmark, Finland, Iceland, Norway, the Russian Federation, and Sweden) are members of the Paris Memorandum of Understanding (MoU) should contribute to PC implementation.

Besides, the PC represents a fundamental policy tool for improving Arctic shipping and a clear economic opportunity for insurance premiums. The authors suggest that underwriters have doubly underestimated the strategic dimension of the PC. Firstly, they have not measured its standardized and procedural foundations as regards risk mitigation thanks to the 'PSC' and PWOM. The PC is a formal risk management tool facilitating their risk appraisal that modifies the insurance premium paradigm and can therefore influence the price of an Arctic risk. Secondly, the PC can allow insurers to orient their institutional positioning in appropriating and transforming this instrument into a mutual 'platform' for closer collaboration with Arctic operators and finally better structuring the future Arctic insurance market. Ultimately, it will allow insurers a new strategic positioning vis-à-vis the IMO on the forthcoming improvements of the PC and affirm themselves as 'Arctic gate-keepers'. Their involvement in the establishment of the Arctic Shipping Best Practice Information Forum ('the Forum') aimed at raising awareness of the $\mathrm{PC}$ and exchanging best practices for Arctic marine operations (AMSA 2017) confirms the key underwriters' role for Arctic navigation safety.

\subsection{The 'Polar Code paradox'}

We observe a number of unsolved issues leading to a 'Polar Code paradox'. The PC is not an exhaustive instrument since certain risks are misevaluated or not fully covered (Fedi and Faury 2016; Henriksen 2014). For instance, the transport and use of HFO are not prohibited while oil spills are considered as major threats to the Arctic environment (AMSA 2009; MARSH 2014). 
Pollutions by ballast water or anti-fouling are simply mentioned in the Recommendations part. Further, voyages in light ice condition for ships with lower ice class or appropriate load lines for polar waters are not taken into consideration (Chircop et al. 2014; Chircop 2015). Even though the PC is designed to reinforce ships' seaworthiness, our interviews showed insurers dreaded the potential increase of companies with no polar experience entering the Arctic shipping at a larger scale. Despite this potential additional business, underwriters paradoxically fear to bear important losses and are reluctant to insure the newcomers. Added to this, in 2015, 71 accidents occurred in Arctic Ocean representing a 29\% casualty rise compared to 2014 and the highest number in a decade (ALLIANZ 2016). While the PC provisions do not deal with the fishing vessels they suffered the greatest number of injuries with cruise ships between 1993 and 2011 (Kum and Sahin 2015). Consequently, some 'black boxes' remain for insurers. As previously reported (Verny and Grigentin 2009; Sarrabezoles et al. 2014), underwriters still face uncertainties due to a lack of data justifying applying a case-by-case approach since they have to fix an insurance premium. This empirical method contrasts with high risks existing in the Arctic and with the formalized risks listed by the PC which is another paradox. Notwithstanding the introduction standards aiming to mitigate risk occurrence and implicitly facilitating the Arctic risk appraisal, their benefits seem limited for marine insurance contract.

Finally, the 'Polar Code paradox' appears to be applicable to other new legal instruments as it describes a situation when a private actor has been engaged in enforcement of standards before those standards have been formalized, so that once they are formalized, the actor is largely blind to the changes. Thus, albeit with a new binding regulation, the effects of this new regulation are (at first) tempered by lacking change of practices. Obviously, even though the PC is a risk-based instrument and constitutes a key step for improving ships' seaworthiness, mitigating risk occurrence and then insurability, marine insurers are still focusing their attention on the lack of data and high uncertainties leading them to exercising extreme prudence and fixing speculative premiums.

\section{Conclusion and future research agenda}

The article analyzed the PC contributions for ship insurability and for underwriters covering Arctic risks with the purpose of evaluating the managerial implications for the Arctic marine insurance. As regards the direct links between the PC provisions and ship insurability which represent a gap in the existing literature, we have highlighted that the PC constitutes a key step for ships' insurability through proceduralization of risk assessment and mitigation. Importantly, this new legal framework imposes predetermined international safety and environmental 
protection standards that were non-harmonized and atomized in national legislations prior to its adoption. Concerning the impacts of the PC on the marine underwriters' risk appraisal for Arctic navigation that is the second gap the authors identified, the interviews carried out have demonstrated the overall positive attitude of the insurers towards the PC while it does not drastically change their risk assessment practices at this stage of its enforcement. Underwriters continue to use their previous practices and follow a case-by-case approach. Nevertheless, the 'PSC' and the PWOM as new safety prerequisites are both formal risk mitigating factors and mandatory documental requirements that insurers have to take into consideration when insuring vessels for Arctic navigation. Consequently, the PC can be considered a 'toolbox' that indirectly structures a part of the insurers' role.

We have also observed several concerns illustrating the 'Polar Code paradox'. Even though identification and response to risks in Arctic shipping has never been so formalized and universalized as with the PC regime, underwriters are not fully familiar with it. In addition, the insurers' work on collecting data on Arctic navigational conditions remains an informal task. Furthermore, even though insurers are interested in the development of Arctic shipping, they are not 'ready' due to the lack of data, prompting fear to bear important losses caused by a major accident. Finally, facing high uncertainties, insurers are reluctant to insure Arctic newcomers with not sufficient experience and low ice class.

The recent PC adoption that does not enable to measure tangible impacts for insurance premium constitutes the main limitation of this research. We nonetheless assume both insurers and shipping operators are now in a transitional phase of adaptation and progressive compliance. While it is too early to consider the PC as a 'game changer' in the Arctic, it is indubitably designed for safer and cleaner shipping in this sensitive area which faced 415 reported shipping incidents in the last decade (ALLIANZ 2017). A recent report issued by the Northern Sea Route Administration recorded 81 violations of its Rules of Navigation during the first nine months of 2017 (NSRA September 2017). These negative figures justify the relevance of PC implementation in the light of an increasingly accessible Arctic Ocean. Underwriters are henceforth legally entitled to monitor the PC provisions as regards safety and environmental requirements and therefore they could play a critical role in reducing risk for shipping companies in the Arctic.

Our future research agenda shall elaborate the actual consequences of the PC on risk mitigation in the long run and estimate more accurately its impacts on insurance premium rates. The future structuration of insurers' networks and their ability to work in closer collaboration 
under standardized criteria to underwrite Arctic risks represent another key challenge to explore. 


\section{References}

Andrey, J. 2010. "Long-Term Trends in Weather-Related Crash Risks." Journal of Transport Geography 18 (2): 247-258. doi:10.1016/j.jtrangeo.2009.05.002.

Bai, J. 2015. "The IMO Polar Code: The Emerging Rules of Arctic Shipping Governance." The International Journal of Marine and Coastal Law 30: 674-699.

Bergström, M., Erikstad, S.O., and Ehlers, S. 2016. "Assessment of the Applicability of Goal and Risk-Based Design on Arctic Sea Transport Systems." Ocean Engineering 128: 183 198.

Berry, J. M. 2002. "Validity and Reliability Issues in Elite Interviewing." PS: Political Science \& Politics 35(4): 679-682.

Blanco-Bazán, A. 2009. "Specific Regulations for Shipping and Environmental Protection in the Arctic: The Work of the International Maritime Organization.” The International Journal of Marine and Coastal Law 24(2): 381-386.

Bonassies, P. and Scapel, C. 2016. Traité de Droit Maritime, 3rd ed. LGDG, Issy-lesMoulineaux. ISBN 978-2-275-03876-6

Braun, V., and Clarke, V. 2006. "Using Thematic Analysis in Psychology." Qualitative research in psychology 3(2): 77-101.

Cariou, P. and Wolff, F-C. 2015. "Identifying Substandard Vessels through Port State Control Inspections: A New Methodology for Concentrated Inspection Campaigns.” Marine Policy 60: 27-39.

Chircop, A. 2013. "Regulatory Challenges for International Arctic Navigation and Shipping in a Evolving Governance Environment." CMI Yearbook: 408-427.

Chircop, A., Reggio, N., Snider, D., and Ray, B. 2014. "Polar Load Lines for Maritime Safety: a Neglected Issue in the International Regulation of Navigation and Shipping in Arctic waters?," CMI Yearbook: 345 - 356.

Chircop, A. 2015. "The load Lines Convention and Arctic Navigation." CMI Yearbook: 414.

Corbett, J.J., Lack, D.A., Winebrake, J.J., Harder, S., Silberman, J.A., and Gold, M. 2010. “Arctic Shipping Emissions Inventories and Future Scenarios." Atmospheric, Chemistry and Physics. doi: 10:9689-9704.

Cullen, P. J. 2015. "Polarseaworthiness - a New Standard of Seaworthiness in the Polar Context?" CMI Yearbook: 413.

De Santis, L., and Ugarriza, D. N. 2000. "The Concept of Theme as Used in Qualitative Nursing Research.” Western Journal of Nursing Research 22(3): 351-372. 
Erikstad, S. O., and Ehlers, S. 2012. "Decision Support Framework for Exploiting Northern Sea Route Transport Opportunities." Ship Technology Research Vol. 59 (2): 34-42. doi:10.1179/str.2012.59.2.003.

Faury, O. 2015. "Risk Management in the Arctic from an Underwriter's Perspective." Proceedings of the IAME 2015 Conference. Kuala Lumpur, Malaysia.

Fedi, L. and Faury, O. 2016. "Les Principaux Enjeux et Impacts du Code Polaire OMI." Le Droit Maritime Français 779 : 323-337.

Fu, S., Zhang, D., Montewka, J., Yan, X., and Zio, E. 2016. "Towards a Probabilistic Model for Predicting Ship Besetting ice in Arctic Waters.” Reliability Engineering \& System Safety 155: 124-136.

Gläser, J., and Laudel, G. 2009. “On Interviewing "Good” and "Bad” Experts.” In A. Bogner, B. Littig, W. Menz (eds.) Interviewing experts, London: Springer.

Glaser, B., and Strauss, A. 1967. "Grounded Theory: The Discovery of Grounded Theory." Sociology The Journal of the British Sociological Association 12: 27-49.

Gold, E. 1999. "Transiting the Northern Sea Route: Shipping and Marine Insurance Interests. In: The 21st century - Turning Point for the Northern Sea Route?” ed. C. L. Ragner, 113122. Kluwer Academic Publishers, Dordrecht, the Netherlands.

Goerlandt, F. and Montewka, J. 2015. "A Framework for Risk Analysis of Maritime Transportation Systems: a Case Study for Oil Spill from Tankers in a ship-ship collision.” Safety Science 76: 42-68.

Gritsenko, D., and Kiiski, T. 2016. "A review of Russian Ice-Breaking Tariff Policy on the Northern Sea Route 1991-2014." Polar Record 52(2): 144-158.

Guedez Soarez, C. and Teixera, A.P. 2011. "Risk Assessment in Maritime Transportation." Reliability Engineering and System Safety 74: 299-309.

Haavik, T.K., 2017. "Remoteness and Sensework in Harsh Environment." Safety science 95: 150-158. doi:10.1016/j.ssci.2016.03.020.

Henriksen, T. 2014. "The Polar Code: Ships in Cold Water - Arctic Issues Examined." CMI Yearbook: 332-344.

IMO. 1974. International Convention for the Safety of Life at Sea (SOLAS). London 1 November 1974. UN Treaty Series vol. 1184 p. 278.

IMO. 1978. International Convention for the Prevention of Pollution from Ships, as modified by the Protocol of 1978 relating thereto (MARPOL 1973/78). London 2 November 1973 and 17 February 1978. UN Treaty Series vol. 1340 p. 62. 
IMO. 2014. Resolution MSC 385(94) of 21 November 2014 and Resolution MEPC 264(68) of 15 May 2015, International Code for Ships Operating in Polar Waters (Polar Code) https://edocs.imo.org/Final Documents/English/MEPC 68-21-ADD.1 (E).doc.

IMO. 2016. MSC. 1/Circ 1519, 6 June 2016, Guidance on Methodologies for Assessing Operational Capabilities and Limitations in Ice. https://docs.imo.org/Final Documents/English/MSC.1-CIRC.1519 (E).docx

Jensen, O. 2008. Arctic Shipping Guidelines: towards a legal regime for navigation safety and environmental protection?" Polar Record 44(2): 107-114.

Johannsdottir, L., and Cook, D. 2014. “An insurance perspective on Arctic Opportunities and Risks, Hydrocarbon exploration and Shipping.” Institute of International Affairs, Centre for Arctic Policy Studies.

Kiiski, T. 2017. "Feasibility of commercial cargo shipping along the Northern Sea Route." Annales Universitatis Turkuensis, University of Turku.

Kronbak, J., and Liu, M. 2010. "The Potential Economic Viability of using the Northern Sea Route (NSR) as an Alternative Route between Asia and Europe." Journal of Transport Geography 18(3): 434-444.

Kujala P., Kämäräinen J., and Suominen, M. 2016. "Challenges for Application of Risk Based Design Approaches for Arctic and Antarctic Operations." 6th International Maritime Conference on Design for Safety, Hamburg, Germany, 28-30.11.2016.

Kum, S. and Sahin, B. 2015. "A Root Cause Analysis for Arctic Marine Accidents from 1993 to 2011." Safety Science 74: 206-220.

Lajeunesse, A., 2012, “A New Mediterranean? Arctic Shipping Prospects for the 21st century," Journal of Maritime Law and Commerce 43(4): 521-537.

Lam, J.S.L., and Lassa, J.A. 2017. "Risk Assessment Framework for Exposure of Cargo and Ports to Natural Hazards and Climate Extremes." Maritime Policy \& Management 44(1): 115. doi: 10.1080/03088839.2016.1245877.

Lam, J. S. L., and Su, S. 2015. "Disruption Risks and Mitigation Strategies: An Analysis of Asian Ports." Maritime Policy \& Management 42 (5): 415-435. doi:10.1080/03088839.2015.1016560.

Lasserre, F. 2014. "Case Studies of Shipping along Arctic Routes. Analysis and Profitability Perspectives for the Container Sector.” Transportation Research Part A 66: 144- 161. 
Lasserre, F., Beveridge, L. Fournier, M., Têtu, P.-L., and Huang, L. 2016. "Polar Seaways? Maritime Transport in the Arctic: An Analysis of Shipowners' Intentions II." Journal of Transport Geography 57: 105-114.

Loughnane, D., Judson, B., and Reid J. 1995. “Arctic Tanker Risk Analysis Project.” Maritime Policy \& Management 22 (1): 3-12. doi:10.1080/03088839500000028.

Luo, M., Shin, S.-H., and Chang, Y.-T. 2017. "Duration Analysis for Recurrent Ship Accidents." Maritime Policy \& Management 44(5): 603-622. doi: 10.1080/03088839.2017.1319983.

Miles, M. B., and Huberman, A. M. 1994. "Qualitative Data Analysis: an Expanded Sourcebook.” Beverly Hills, Sage publishing.

Molenaar, E.J. 2008. “Arctic Marine Shipping Overview of the International Legal Framework, Gaps and Options.” Journal of Transnational Law \& Policy (Vol. 18.2): 290 - 316.

Montewka, J., Goerlandt, F., Kujala, P., and Lensu, M. 2015. “Towards a Probabilistic Model of a Ship Performance in Dynamic Ice.” Cold Regions Science Technology 112: 14-28.

Notteboom, T., and J. S. L. Lam. 2014. "Dealing with Uncertainty and Volatility in Shipping and Ports." Maritime Policy \& Management 41 (7): 611-614. doi:10.1080/03088839.2014.965297.

Ørts Hensen C., Grønsedt, P., Lindstrøm Graversen C., and Hendriksenn, C. 2016. "Arctic Shipping, Commercial Opportunities and Challenges.” CBS Maritime, ISBN 978-87-9326203-4. Accessed 3 March $2017 . \quad \underline{\text { htps://services- }}$ webdav.cbs.dk/doc/CBS.dk/Arctic\%20Shipping\%20\%20Commercial\%20Opportunities\%20and\%20Challenges.pdf

Patton, M. Q. 2002. “Qualitative Interviewing.” Qualitative Research and Evaluation Methods 3: $344-347$.

Pruyn, J. F. J. 2016. "Will the Northern Sea Route Ever Be a Viable Alternative?” Maritime Policy \& Management 43(6): 661-675. doi: 10.1080/03088839.2015.1131864.

Sampson, H., and Bloor, M. 2007. "When Jack Gets Out of the Box: the Problems of Regulating a Global Industry." Sociology 41(3): 551-569.

Sarrabezoles, A., Lasserre, F., and Hagouagn'rin, Z. 2014. "Arctic Shipping Insurance: Towards a Harmonisation of Practices and Costs?" Polar Record 52(04): 393-398. doi:10.1017/S0032247414000552.

Stokke, O.S. 2011. "Environmental Security in the Arctic. The Case for Multilevel Governance.” International Journal LXVI(4): 835-848. 
Tetley, W. 2003. International Maritime and Admiralty Law. ISBN/ISSN/: 2-89451-612-6. Editions Yvon Blais, Québec.

Tikka, K., Riska, K., and Liu, S. 2008. "Tanker Design Considerations for Safety and Environmental Protection of Arctic Waters: Learning from Past Experience.” WMU Journal of Maritime Affairs Vol. 7 (1): 189-204. doi:10.1007/BF03195131.

Uğurlu, O., Kum, S. and Aydoğdu Y. V. 2017. "Analysis of Occupational Accidents Encountered by Deck Cadets in Maritime Transportation." Maritime Policy \& Management 44(3): 304-322. doi: 10.1080/03088839.2016.1245449.

UNCLOS. 1982. United Nations Convention on the Law of the Sea. Montego Bay, 10 December 1982. UN Doc. A/CONF.62/122, 7 October 1982.

Verny, J., and Grigentin, C. 2009. "Container shipping on the Northern Sea Route." International Journal of Production Economics 122: 107-117. doi:10.1016/j.ijpe.2009.03.018.

Vilko, J. P. P., and J. M. Hallikas. 2012. "Risk Assessment in Multimodal Supply Chains." International Journal of Production Economics 140 (2): 586-595. doi:10.1016/j.ijpe.2011.09.010.

Wang, J. 2006. "Maritime Risk Assessment and its Current Status." Quality and Reliability Engineering International 22 (1): 3-19. doi:10.1002/qre.744. 


\section{Appendix 1: Data sources}

Professional reports

ALLIANZ. 2017. Safety and Shipping Review. An Annual Review of Trends and Developments in Shipping Losses and Safety. Accessed 3 September 2017. http://www.agcs.allianz.com/assets/PDFs/Reports/AGCS_Safety_Shipping_Review 2017. pdf

ALLIANZ. 2016. Safety and Shipping Review. An Annual Review of Trends and Developments in Shipping Losses and Safety. Accessed 2 February 2017. http://www.agcs.allianz.com/assets/PDFs/Reports/AGCS_Safety_Shipping_Review_2016. pdf

AMSA. 2017. Status on Implementation of the AMSA 2009 Report Recommendations. May 2017. Accessed 1 September $2017 . \quad$ https://oaarchive.arcticcouncil.org/bitstream/handle/11374/1957/PAME_4thAMSA Implementation Progress Report for the period 2015-2017.pdf

AMSA. 2009. Arctic Marine Shipping Assessment 2009 Report. Arctic Council, April 2009, second printing. Accessed 3 February 2017. http://www.arcticcouncil.org/index.php/en/documentarchive/category/20-main-documents-from-nuuk

CEFOR (The Nordic Association of Marine Insurers). 2016. Annual Report 2016. Accessed 1 September 2017. http://www.cefor.no/About-Cefor/Annual-Reports/

CEFOR. 2012. Check list for Underwriters and Owners/Managers for Assessing Risks Associated with Voyages in Arctic Waters. Accessed 1 September 2017. http:/www.cefor.no/Documents/Clauses/Arctic\%20Sailing/WP-ArcticSailingsCheckList12-10-09.pdf

FORUM PAME 2017. Arctic Shipping Best Practice Information Forum (the FORUM). Terms of Reference. (Revisions and final as per PAME II-2017). Accessed 1 September 2017. https://pame.is/index.php/fundur1/the-arctic-marine-shipping-best-practices-informationforum

IPCC. 2011. Summary for Policymakers: Intergovernmental Panel on Climate Change Special Report on Managing the Risks of Extreme Events and Disasters to Advance Climate Change Adaptation. Cambridge: Cambridge University Press.

IPPC. 2014. Climate Change 2014. Impacts, Adaptation and Vulnerability. Contributions of the Working Group II to the Fifth Assessment Report [...]. Accessed 3 January 2017. https://www.ipcc.ch/pdf/assessment-report/ar5/wg2/ar5_wgII_spm_en.pdf 
IUMI (International Association of Marine Insurance). 2017 Global Marine Insurance Report. Author: Seltmann, A. IUMI 2017, Toyko. Accessed 1 October 2017. https://iumi.com/statistics

LLOYD'S. 2011. Arctic Opening: Opportunity and Risk in the High North. Emmerson, C., and Lahn, G. Lloyd's Chatam House, London. Accessed 3 January 2017. http://Arctic_Risk_Report_webview.pdf

MARSH. 2014. Arctic Shipping: Navigating the Risks and Opportunities. Marsh Risk $\begin{array}{lllll}\text { Management } & \text { Research. } & \text { Accessed } & 5 & \text { January }\end{array}$ https://www.marsh.com/uk/insights/research/arctic-shipping-navigating-the-risks-andopportunities.pdf.

Northern Sea Route Administration (NSRA). 2017. Violation of the Navigation Rules on the NSR. Accessed 5 October 2017. http://www.arctic-lio.com/node/277

WEF (World Economic Forum). 2013. Global Risks 2013 Eighth Edition: An Initiative of the Risk Response Network. Geneva: World Economic Forum.

\section{Interviews}

1. Senior manager in a marine insurance company (H\&M and P\&I), Norway, January $9^{\text {th }}$ 2017.

2. Loss control manager in a marine insurance company (H\&M), Finland, 10.01.2017.

3. Senior underwriter in a marine insurance company (H\&M), Finland, 19.01.2017.

4. Senior underwriter in a marine insurance company (H\&M and P\&I), Norway, 24.01.2017.

5. Underwriting Manager, in a marine insurance company (H\&M), France, 25.01.2017.

6. Senior Marine Hull Underwriter in a marine insurance company (H\&M), France, 27.01.2017

7. Head of Marine Underwriting Department in an insurance company (H\&M), Russia, 02.02 .2017

8. Head of P\&I Department in an insurance company (P\&I), Russia, 03.03.2017.

9. Underwriters, in a marine insurance company (H\&M), France, 13.03.2017

10. Managing Director, in a marine insurance company (P\&I), France, 10.03.2017 
Table 1. Key factors of insurance premium outside Arctic

\begin{tabular}{|c|c|c|c|}
\hline Ship & Navigating limits & $\begin{array}{c}\text { Insurance } \\
\text { coverage }\end{array}$ & $\begin{array}{c}\text { Insured's risk } \\
\text { profile }\end{array}$ \\
\hline $\begin{array}{ll}\text { - } & \text { Type, size, age } \\
\text { - } & \text { Type of motive } \\
\text { power } \\
\text { - } & \text { Nature of goods } \\
\text { carried } \\
\text { - } \quad \text { Last survey } \\
\text { - Legal } \\
\text { compliance } \\
\text { (ISM and ISPS) } \\
\text { - Ship's } \\
\text { classification } \\
\text { - Ship's value }\end{array}$ & $\begin{array}{c}\text { - Chosen areas } \\
\text { and ports } \\
\text { - Geographic } \\
\text { exclusions }\end{array}$ & $\begin{array}{l}\text { - Scope of the } \\
\text { cover } \\
\text { - } \quad \text { Sums } \\
\text { insured } \\
\text { - Additional } \\
\text { risk } \\
\text { - Deductibles }\end{array}$ & $\begin{array}{ll}\text { - } & \text { Number of } \\
\text { vessels } \\
\text { - } & \text { Past claims } \\
\text { experience }\end{array}$ \\
\hline
\end{tabular}

Source: Authors, based on Tetley (2003), Bonassies and Scapel (2016) 
Table 2: Polar Code and risk mitigation: underwriters' view

\begin{tabular}{|c|c|}
\hline Benefits & Shortcomings \\
\hline 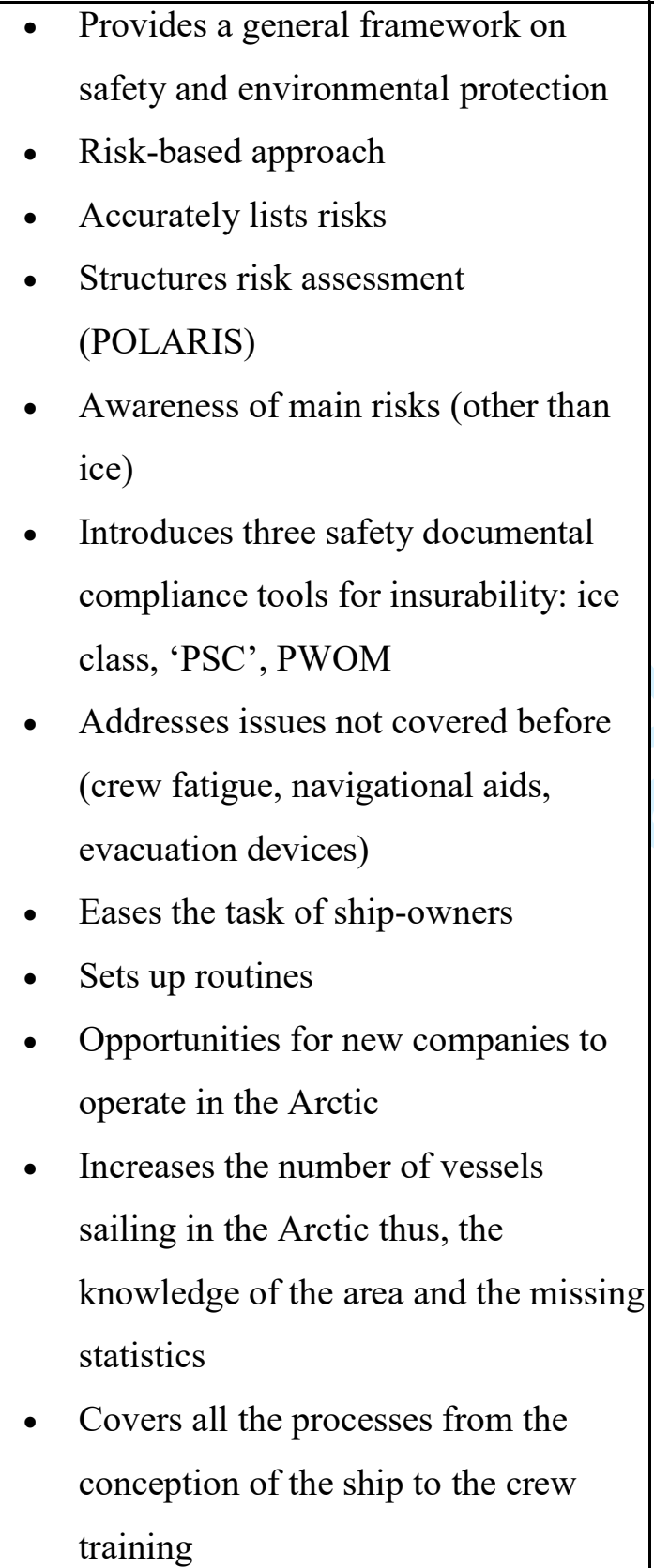 & 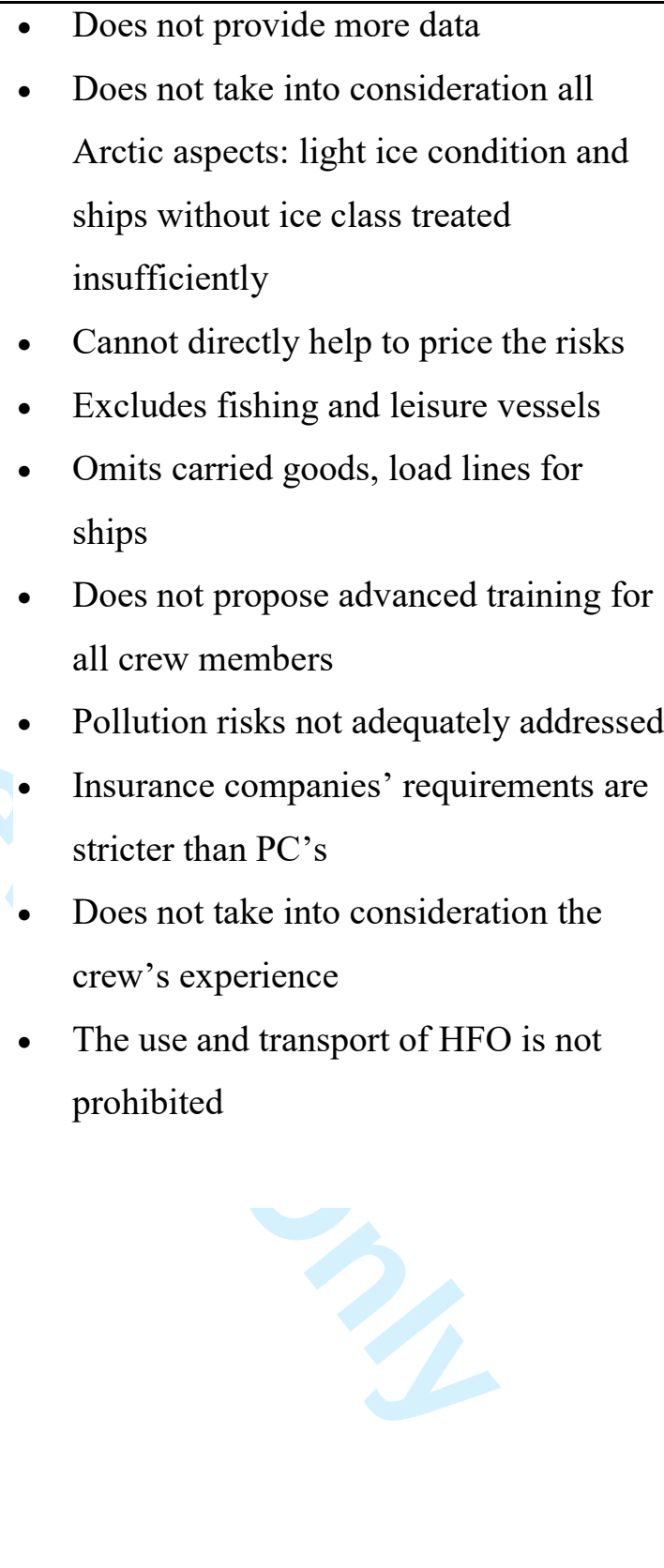 \\
\hline
\end{tabular}

Source: Authors based on interviews 
Figure 1. Key criteria for insurance premium in Arctic

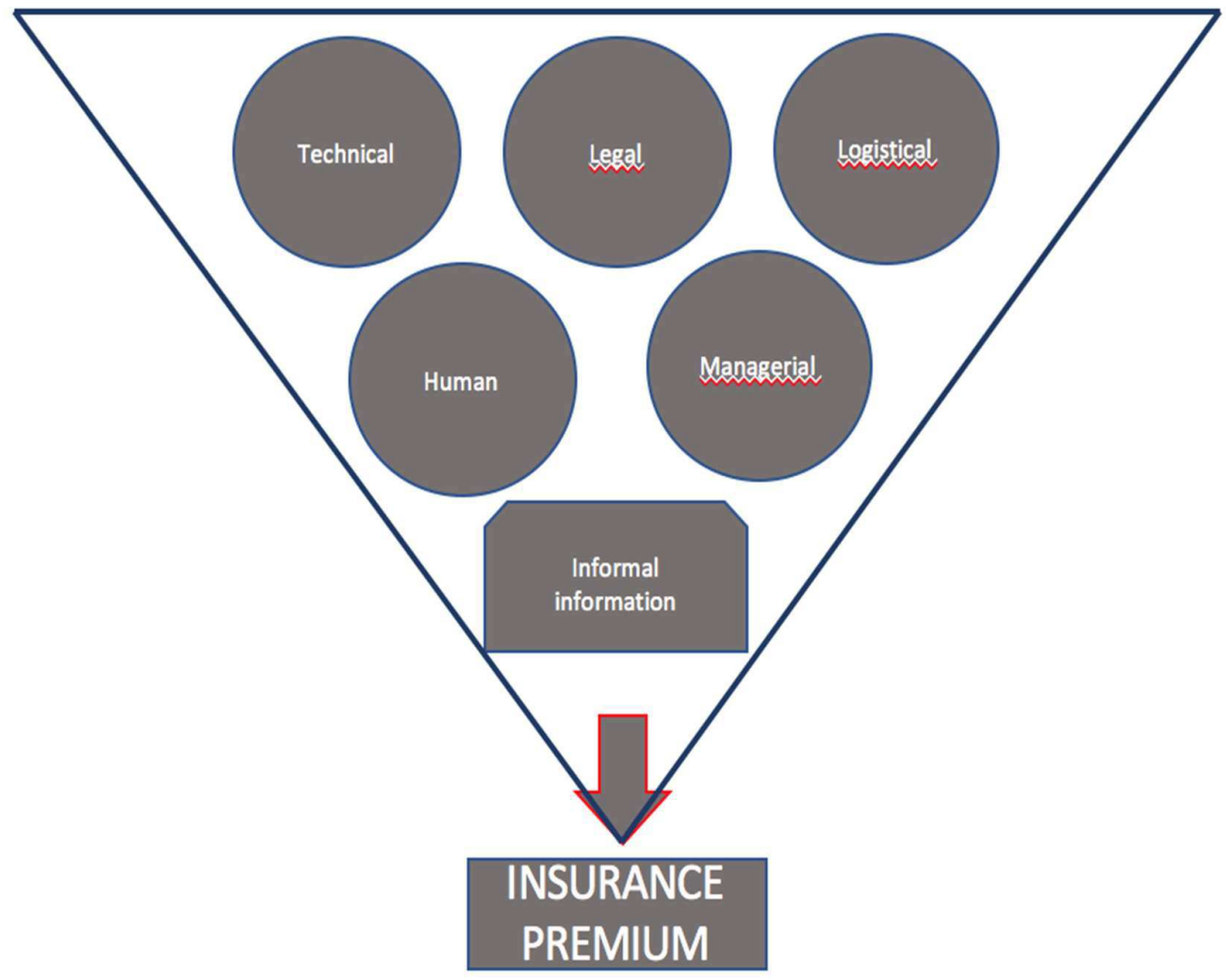

Source: Authors based on CEFOR 2012 
Figure 2. Fixing insurance premium in the Arctic context

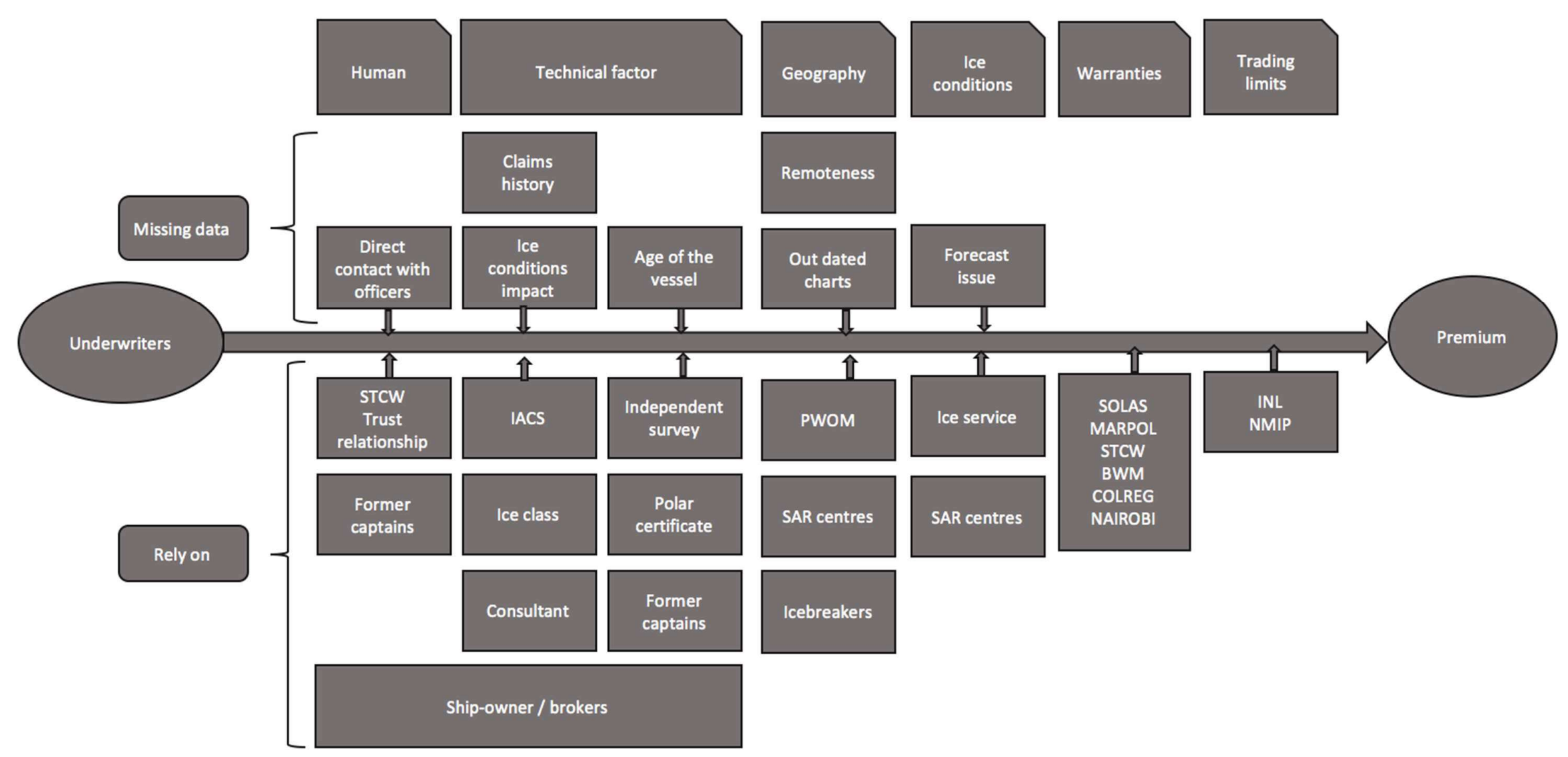

Source: Authors 